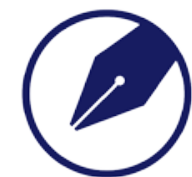

\title{
Recovery of Uranium from Alkaline Ore Leach Solution Using a Precipitating Method
}

\author{
Sujoy Biswas*, V. H. Rupawate, M.L. Sahu \\ Uranium Extraction Division, Materials Group, Bhabha Atomic Research Centre, Trombay, Mumbai - 400085, India \\ Email: sujoyb@barc.gov.in
}

\begin{abstract}
In this paper, recovery of uranium from carbonate ore leach solution has been reported using a novel precipitation method. The method is based on the precipitation of uranium as yellow color magnesium diuranate (MDU) using $\mathrm{MgO} / \mathrm{NaOH}$ mixture. The process has been finalized by optimizing various process parameters such as concentration of $\mathrm{CO}_{3}^{2-}, \mathrm{HCO}_{3}^{-}, \mathrm{HCl}, \mathrm{NaOH}, \mathrm{MgO}$ and reaction temperature. The overall recovery of uranium was $97 \%$. The chemical composition of the yellow precipitate (MDU) was evaluated employing XRD technique. A process flow-sheet has been developed for recovery of $\mathrm{U}(\mathrm{VI})$ from low concentration carbonate ore leach solution.
\end{abstract}

Keywords: uranium, carbonate ore, leaching, MDU, XRD

\section{Introduction}

Uranium is extremely useful element for the development of nuclear energy due to its use as a nuclear fuel in nuclear reactor. The nuclear fuel cycle states with the mining of uranium from earth crust, fuel fabrication, spent fuel reprocessing and end with the safe disposal of nuclear waste. In a developing country like India, the nuclear power plays an important role for long term energy security and economic development of the country since India has shortage of fossil fuels ${ }^{[1-3]}$. Currently, only $3 \%$ of total energy has come from nuclear contribution and $25 \%$ nuclear contribution is expected in 2050 to sustain the GDP growth in the range of $8-10 \%{ }^{[4]}$. The increasing demand of nuclear power in India has triggered interest in the exploration of various resources of natural uranium including lean sources like carbonate ore situated at Tummalapalle, India ${ }^{[5]}$. Further, the deposit of Tummalapalle is lower grade $\left(\sim 0.042 \% \mathrm{U}_{3} \mathrm{O}_{8}\right)$ but reasonably large reserve and it is confined in the host rock of alkali (dolomite and calcite). The Tummalapalle ore deposit becomes important due to its large amount of uranium content ${ }^{[6]}$. At present, the recovery of uranium from Tummalapalle ore is carried out using alkaline leaching process where the ore is leached with a mixture of $\mathrm{Na}_{2} \mathrm{CO}_{3} / \mathrm{NaHCO}_{3}$ in presence of air at elevated pressure and temperature in an autoclave ${ }^{[7-8]}$. Finally the uranium in leach liquor is precipitated with $\mathrm{NaOH}$ solution as sodium diuranate (SDU) at high temperature as per following chemical reactions ${ }^{[8]}$ :

$$
\begin{aligned}
& \mathrm{NaHCO}_{3}+\mathrm{NaOH}=\mathrm{Na}_{2} \mathrm{CO}_{3}+\mathrm{H}_{2} \mathrm{O} \\
& 2 \mathrm{Na}_{4} \mathrm{UO}_{2}\left(\mathrm{CO}_{3}\right)_{3}+6 \mathrm{NaOH}=\mathrm{Na}_{2} \mathrm{U}_{2} \mathrm{O}_{7}+6 \mathrm{Na}_{2} \mathrm{CO}_{3}+3 \mathrm{H}_{2} \mathrm{O}
\end{aligned}
$$

The pyrite and other sulphide minerals present in the alkaline ore are also oxidized to sodium sulphate and solubilized in the reaction medium during alkaline pressure leaching according to following equation:

$$
2 \mathrm{Fe}_{2}+7 \mathrm{O}_{2}+8 \mathrm{Na}_{2} \mathrm{CO}_{3}+6 \mathrm{H}_{2} \mathrm{O}=2 \mathrm{Fe}(\mathrm{OH})_{2}+4 \mathrm{Na}_{2} \mathrm{SO}_{4}+8 \mathrm{NaHCO}_{3}
$$

For complete precipitation, the minimum concentration of uranium in feed solution must be $2.4 \mathrm{~g} / \mathrm{L}^{[9-10]}$. Currently, the concentration of uranium in feed solution is $<1 \mathrm{~g} / \mathrm{L}$ and it is not possible to precipitate the uranium as SDU completely using the existing process. Further, the mean particle size of SDU in the existing process is very less $(6-8 \mu \mathrm{m})$ which creates difficulty in settling and filtration of SDU cake. Considering vast deposit of uranium in Tummalapalle ore, it is important to develop an alternate chemical process for complete recovery of uranium from such lean solutions. The aim of 
the present study is to develop an efficient chemical process for the recovery of uranium from such ore leach solution containing $<1 \mathrm{~g} / \mathrm{L}$ of uranium. In our earlier work, we have demonstrated an improved precipitation method for recovery of uranium from carbonate solution as MDU without any addition of acids ${ }^{[11]}$. In the present study uranium from Tummalapalle ore leach solution ([U]: $0.74 \mathrm{~g} / \mathrm{L}$ ) is precipitated as magnesium diuranate (MDU) in presence of $\mathrm{MgO} / \mathrm{NaOH}$ mixture at $50^{\circ} \mathrm{C}$. The main focus of the present work is the mechanism of uranium precipitation as MDU from carbonate leach solution. The $\mathrm{pH}$ of leach liquor was adjusted from 9 to 7 and requisite amount of $\mathrm{MgO}$ was added to the solution. Further, excess amount of $\mathrm{NaOH}$ was added in the solution to precipitate all uranium as $\mathrm{MgU}_{2} \mathrm{O}_{7}$ at $\mathrm{pH} \sim 12.5$. The average particle size of the $\mathrm{MgU}_{2} \mathrm{O}_{7}$ particles was $20 \mu \mathrm{m}$ and overall uranium recovery of the process was $97 \%$. The composition of final precipitate was characterized using X-ray diffraction (XRD) technique. The present process was compared with the earlier one, SDU process and it was observed that the present process has high efficiency with improved average particle size distribution.

\section{Experimental}

\subsection{Reagents and chemicals}

Sodium hydroxide (A.R. grade, 99\% pure), magnesium oxide (Industrial grade), poly vinyl chloride (A.R. grade, $>$ 97\% pure), tetrahydrofuran (A.R. grade, $>97 \%$ pure) were used without any further purification. The alkaline ore leach solution containing $0.74 \mathrm{~g} / \mathrm{L}$ U was obtained from Uranium Corporation of India Limited, Tummalapalle, India. All the other reagents used in the experiments were of A.R. grade. Table $1 \& 2$ showed the specification of alkaline ore leach solution used throughout the experiments ${ }^{[11]}$.

Table 1. Major composition of ore leach solution

\begin{tabular}{cc}
\hline Parameter & Value \\
\hline$[\mathrm{U}]$ & $0.74 \mathrm{~g} / \mathrm{L}$ \\
Specific gravity & 1.14 \\
Total dissolved solid & $154.72 \mathrm{~g} / \mathrm{L}$ \\
$\mathrm{SO}_{4}^{2-}$ & $69.66 \mathrm{~g} / \mathrm{L}$ \\
$\mathrm{CO}_{3}^{2-}$ & $13.79 \mathrm{~g} / \mathrm{L}$ \\
$\mathrm{HCO}_{3}^{-}$ & $18.23 \mathrm{~g} / \mathrm{L}$ \\
$\mathrm{F}^{-}$ & $16 \mu \mathrm{g} / \mathrm{mL}$ \\
\hline
\end{tabular}

Table 2. Elemental composition of ore leach solution

\begin{tabular}{cc}
\hline Elements & Concentration, $\mu \mathrm{g} / \mathrm{mL}$ \\
\hline $\mathrm{U}$ & 740 \\
$\mathrm{Fe}$ & 12 \\
$\mathrm{Al}$ & 31 \\
$\mathrm{Cr}$ & $<1$ \\
$\mathrm{Mg}$ & 10 \\
$\mathrm{Mn}$ & $<1$ \\
$\mathrm{Ni}$ & $<1$ \\
$\mathrm{~B}$ & 12 \\
$\mathrm{Cd}$ & $<0.12$ \\
$\mathrm{Co}$ & $<0.12$ \\
$\mathrm{Ce}$ & $<0.12$ \\
$\mathrm{Sm}$ & $<0.12$ \\
$\mathrm{Gd}$ & $<0.12$ \\
$\mathrm{Dy}$ & $<0.12$ \\
$\mathrm{Sr}$ & $<0.12$ \\
$\mathrm{Eu}$ & $<0.12$ \\
$\mathrm{Y}$ & $<0.12$ \\
$\mathrm{Yb}$ & $<0.12$ \\
\hline
\end{tabular}

\subsection{Instruments}

Inductively Coupled Plasma Optical Emission Spectrophotometer (ICP OES, Model No. JY 238) was used for determination of uranium and other trace impurities in various samples. Laser Diffraction Particle Size Analyzer from CILAS (Model No. CILAS 1064 Liquid) was used for particle size analysis of uranium cake. A Thermo-Orion make pH 
meter containing Ross make glass electrode was used to monitor $\mathrm{pH}$ of the solution. X-ray diffraction spectrophotometer (SIEMENS D-5000) was used in the present study for chemical compositional characterization of uranium cakes. The $\mathrm{X}$-ray diffraction of the samples were performed using $\mathrm{Cu} \mathrm{K} \alpha$ radiation $(\lambda=1.54 \AA)$ using a few milligram of a sample placed in a sample holder. The samples were mounted in a glass plate with the help of a solution of polyvinylchloride in Tetrahydrofuran. A step size of 0.02 for $2 \theta$ and a speed of $0.3 \%$ min were used for the analysis.

\subsection{Experimental procedure}

The precipitation reaction was carried out in batch mode using $5 \mathrm{~L}$ glass reactor containing $4 \mathrm{~L}$ carbonate leach solution. The glass reactor contains a marine type 3 bladed propeller for mixing of solution, constant temperature heater, thermocouple, digital temperature controller. The addition of chemicals such as $\mathrm{MgO}$ was carried out in solid form in the leach liquor whereas addition of alkali $(\mathrm{NaOH})$ was carried out in slurry mode. The solution mixture was stirred at constant rpm (600) for a period of 1 hour. $5 \mathrm{~mL}$ samples were withdrawn from the glass reactor with the help of glass pipette at different time intervals for checking the uranium concentration of the solution. The completion of the reaction was assured by checking the concentration of uranium in the filtrate. After completion of precipitation reaction, the uranium slurry was filtered under vacuum and cake was dried in an oven at $110^{\circ} \mathrm{C}$ for a period of 3 hours.

\section{Results and discussions}

\subsection{Effect of addition of hydrochloric acid}

Table 3. Effect of $\mathrm{HCl}$ on uranium recovery from carbonate leach solutions. NaOH: $20 \mathrm{~g} / \mathrm{L}$; T: $25^{\circ} \mathrm{C}$; [HCl]: $11 \mathrm{M}$; Stirring speed: $600 \mathrm{rpm}$; [U]feed: $0.74 \mathrm{~g} / \mathrm{L}$

\begin{tabular}{cccc}
\hline Volume of $\mathrm{HCl}, \mathrm{mL} / \mathrm{L}$ & {$[\mathrm{U}]_{\text {filtrate }}, \mu \mathrm{g} / \mathrm{mL}$} & \% Recovery & Mean diameter, $\mu \mathrm{m}$ \\
\hline 75 & 46 & 93.78 & 10 \\
100 & 38 & 94.86 & 12 \\
125 & 20 & 97.29 & 16 \\
150 & 26 & 96.48 & 20 \\
\hline
\end{tabular}

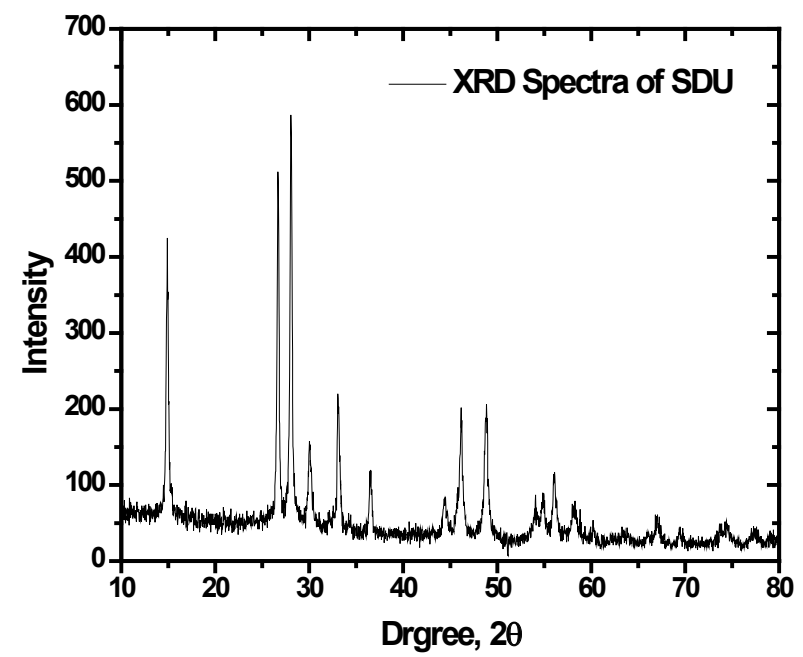

Figure 1. XRD profile of sodium diuranate (SDU) precipitated from carbonate leach solution using $\mathrm{NaOH}$

Literature data indicates that the uranium from carbonate leach solution was generally precipitated as yellow color SDU using $\mathrm{NaOH}$ at $40-50^{\circ} \mathrm{C}$ according to equation 2. The average particle size of the SDU precipitate is in the range of 6-8 $\mu \mathrm{m}$ which create problem in settling the yellow cake at the bottom of the reactors ${ }^{[9,10,12]}$. Further, it is reported that if the uranium concentration goes below a minimum value $(2.4 \mathrm{~g} / \mathrm{L})$, complete precipitation of uranium is not possible and most of the SDU particles remain in solution as colloidal state. Currently, the uranium concentration in Tummalapalle leach liquor is $0.74 \mathrm{~g} / \mathrm{L}$ with the presence of other anions $69.66 \mathrm{~g} / \mathrm{L} \mathrm{SO}_{4}^{2-}, 13.79 \mathrm{~g} / \mathrm{L} \mathrm{CO}_{3}^{2-}$ as well as $18.23 \mathrm{~g} / \mathrm{L} \mathrm{HCO}_{3}^{-}$ and $\mathrm{NaOH}$ it fails to precipitate uranium completely as SDU. The presence of complexing anion, $\mathrm{CO}_{3}{ }^{2-}$ prevents the precipitation of uranium from carbonate leach solution when the uranium concentration goes below $2.4 \mathrm{~g} / \mathrm{L}$. To reduce the effect of $\mathrm{CO}_{3}^{2-}, \mathrm{HCl}$ is added in carbonate leach solution and its $\mathrm{pH}$ is reduced from 9.1 to $\sim 7$ where most of the carbonate converts to bicarbonate. According to pourbaix diagram at $\mathrm{pH} \sim 7, \mathrm{U}(\mathrm{VI})$ mainly exist as $\left(\mathrm{UO}_{2}\right)_{3}(\mathrm{OH})_{5}{ }^{+}$and trace 
amount of $\mathrm{UO}_{2}\left(\mathrm{CO}_{3}\right)_{3}{ }^{2-}$ and at $\mathrm{pH}>8 \mathrm{U}(\mathrm{VI})$ exist as a mixtures of $\mathrm{UO}_{2}\left(\mathrm{CO}_{3}\right)_{3}{ }^{2-}$ and $\mathrm{UO}_{2}\left(\mathrm{CO}_{3}\right)_{4}{ }^{4-}{ }^{[12-14]}$. After conversion of $\mathrm{UO}_{2}\left(\mathrm{CO}_{3}\right)_{4}{ }_{4}^{4-}$ complex to $\left(\mathrm{UO}_{2}\right)_{3}(\mathrm{OH})^{5+}, 25 \mathrm{~g} \mathrm{NaOH}$ slurry was added in $1 \mathrm{~L}$ of leach solution with constant stirring at $25^{\circ} \mathrm{C}$. A yellow color precipitate was obtained with the average particle size of $10 \mu \mathrm{m}$ and the overall uranium recovery was $\sim 93 \%$ (Table 3). XRD study showed that the yellow precipitate was sodium diuranate (SDU) (Figure 1). With increase in amount $\mathrm{HCl}$ from $75 \mathrm{~mL} / \mathrm{L}$ to $125 \mathrm{~mL} / \mathrm{L}$ there was an increase in uranium recovery from $\sim 93 \%$ to $97 \%$ as well as mean particle diameter from 10 to $16 \mu \mathrm{m}$. Further rise in acid volume/concentration, there is no increase in overall uranium recovery of the process, although there is an increase in average diameter of SDU particles. The increase in particle size of SDU is due to the decrease in carbonate as well as $\mathrm{UO}_{2}\left(\mathrm{CO}_{3}\right)_{4}{ }^{4}$ ions concentration in the reaction medium which accelerate the agglomeration of primary particle formed during precipitation of uranium.

\subsection{Effect of MgO}

The effect of $\mathrm{MgO}$ on uranium recovery was studied for obtaining large particle size of precipitate by spending minimum amounts of chemicals. With increase in $\mathrm{MgO}$ concentration in reaction medium, there was an increase in efficiency of the process as well as particle size of the uranium cake (Table 4). The uranium precipitation reaction follows in two steps forming final compound, $\mathrm{MDU}$ at $\mathrm{pH} \sim 12.5$. In the first step, addition of $\mathrm{HCl}$ will destroy the $\mathrm{UO}_{2}\left(\mathrm{CO}_{3}\right)_{4}{ }^{4-}$ complexes present in the solution at $\mathrm{pH}<7$. In the next step, addition of $\mathrm{MgO}$ in reaction medium at $\mathrm{pH} \sim 7$ leads to formation of $\mathrm{Mg}^{2+}$ through hydration which acts as a coagulant for uranium precipitation. The hydration of $\mathrm{MgO}$ at neutral $\mathrm{pH}$ is proceeding through following equations ${ }^{[15]}$ :

$$
\begin{aligned}
& \mathrm{MgO}+\mathrm{H}_{2} \mathrm{O} \rightarrow \mathrm{MgOH}^{+}+\mathrm{OH}^{-} \\
& \mathrm{MgOH}^{+}+\mathrm{OH}^{-} \rightarrow \mathrm{MgOH}^{+} . \mathrm{OH}^{-} \\
& \mathrm{MgOH}^{+} . \mathrm{OH}^{-} \rightarrow \mathrm{Mg}^{2+}+2 \mathrm{OH}^{-} \\
& \mathrm{Mg}^{2+}+2 \mathrm{OH}^{-} \rightarrow \mathrm{Mg}(\mathrm{OH})_{2}
\end{aligned}
$$

Table 4. Effect of addition of $\mathrm{MgO}$ on uranium recovery from carbonate leach solutions. NaOH: $20 \mathrm{~g} / \mathrm{L}$; T: $25^{\circ} \mathrm{C}$; [HCl]: $11 \mathrm{M}$; Volume of $\mathrm{HCl}: 75 \mathrm{~mL} / \mathrm{L}$; Stirring speed: $600 \mathrm{rpm}$; [U]feed: $0.74 \mathrm{~g} / \mathrm{L}$

\begin{tabular}{cccc}
\hline$[\mathrm{MgO}], \mathrm{g} / \mathrm{L}$ & {$[\mathrm{U}]_{\text {filtrate }}, \mu \mathrm{g} / \mathrm{mL}$} & \% U Recovery & Mean diameter, $\mu \mathrm{m}$ \\
\hline 0.5 & 41 & 94.50 & 9.74 \\
1 & 37 & 95 & 12 \\
1.5 & 33 & 95.54 & 18 \\
\hline
\end{tabular}

Further, the addition of $\mathrm{NaOH}$ in solution will lead to increase in $\mathrm{pH}$ of the reaction medium leading to complete precipitation of uranium as yellow color magnesium diuranate (MDU). The precipitation of uranium in hydroxide medium proceeds through formation of negative charge colloid particles called primary particles. The addition of $\mathrm{NaOH}$ will increase $\mathrm{HO}^{-}$ions in the solution forming negative charge colloid particles having various chemical compositions. The whole processes for $\mathrm{U}(\mathrm{VI})$ precipitation from carbonate leach solution can be presented by the following steps ${ }^{[16-18]}$ :

Step (1)

$$
\begin{aligned}
& \mathrm{CO}_{3}{ }^{2-}+\mathrm{HCl} \rightarrow \mathrm{HCO}_{3}^{-}+\mathrm{Cl}^{-} \\
& \mathrm{UO}_{2}\left(\mathrm{CO}_{3}\right)_{4}{ }^{4-}+2 \mathrm{HCl} \rightarrow \mathrm{UO}_{2}\left(\mathrm{CO}_{3}\right)_{3}{ }^{2-}+\mathrm{H}_{2} \mathrm{O}+\mathrm{CO}_{2}+2 \mathrm{Cl}^{-} \\
& \mathrm{UO}_{2}\left(\mathrm{CO}_{3}\right)_{3}{ }^{2-}+5 \mathrm{H}_{2} \mathrm{O} \rightarrow\left(\mathrm{UO}_{2}\right)_{3}(\mathrm{OH})_{5}{ }^{+}+\mathrm{HCO}_{3}^{-}
\end{aligned}
$$

After addition of $\mathrm{NaOH}$ :

Step (2)

$\left(\mathrm{UO}_{2}\right)_{3}(\mathrm{OH})_{5}^{+} \leftrightarrow\left(\mathrm{UO}_{2}(\mathrm{OH})_{2-n}\right)_{m}{ }^{n-m}$

Step (3) 
Step (4)

$$
\left(\mathrm{UO}_{2}(\mathrm{OH})_{2-n}\right)_{m}{ }^{n-m}+\mathrm{OH}^{-} \rightarrow \mathrm{UO}_{2}(\mathrm{OH})_{2 m} \rightarrow\left(\mathrm{UO}_{2}(\mathrm{OH})_{2}\right)_{m} \mathrm{OH}^{-}
$$

Step (5)

$$
\mathrm{HCO}_{3}^{-}+\mathrm{OH}^{-} \rightarrow \mathrm{CO}_{3}^{2-}+\mathrm{H}_{2} \mathrm{O}
$$

Where $\mathrm{M}$ represents the cation present in the medium.

Step (1) represents the formation of less complexing $\mathrm{HCO}_{3}{ }^{-}$ions from more complexing $\mathrm{CO}_{3}{ }^{2-}$ ions by adding $\mathrm{HCl}$. On the other side, at $\mathrm{pH} \sim 7$, the highly stable complex, $\mathrm{UO}_{2}\left(\mathrm{CO}_{3}\right)_{4}{ }_{4}^{4-}$ converts in to $\mathrm{UO}_{2}\left(\mathrm{CO}_{3}\right)_{3}{ }^{2-}$ and $\left(\mathrm{UO}_{2}\right)_{3}(\mathrm{OH})^{5+}{ }^{[12-14]}$. Step (2) shows the formation of U(VI)-hydroxo complexes, where " $m$ " describes the degree of polymerization. Rush et al. ${ }^{[19]}$ observe by ultracentrifuge measurement that the dimer is the predominate species and polymerization does not exceed three. Further interaction of polymers with hydroxide ions lead to the formation of metastable colloid particles of uranyl hydroxide which is negatively charged in nature as shown in step (3) ${ }^{[20]}$. The stability of colloid is highly sensitive to the presence of neutral electrolytes and its charge on the cations or anions opposite to the charge of colloidal particles. The transition of solute species into the solid phase consists of five subsystem (i) formation of various complexes, (ii) embrionation, (iii) nucleation (iv) micellation (formation of primary particles) and (v) secondary aggregation. The role of $\mathrm{Mg}^{2+}$ is to bring the small negative charge primary particles (micelles) together to form bigger particles/agglomerates (secondary aggregation). Since, such kind of phenomena called coagulation depends on the charge of the cation and its concentrations, with increase in cationic charge or concentrations will lead to increase in formation of bigger agglomerate due to more coagulation (agglomeration). Step (4) represents the phenomena of coagulation of negatively charged colloidal particles in presence of metal ion $\left(\mathrm{Mg}^{2+}\right)$. In alkaline medium the excess $\mathrm{HCO}_{3}^{-}$is converted in to $\mathrm{CO}_{3}^{2-}$ in presence of $\mathrm{NaOH}$ (Step 5). Tomazic et al. ${ }^{[17]}$ observe that the presence of high charge cations such as $\mathrm{Ba}^{2+}$ and $\mathrm{La}^{3+}$ during precipitation of uranium with ammonia as ammonium di uranate (ADU) leads to increase in precipitation rate and formation of bigger ADU particles.

\subsection{Effect of temperature}

The variation of temperature is an important parameter for controlling the kinetics of a precipitation reaction. The effects of temperature on uranium precipitation from carbonate leach solution were investigated by varying temperature of the reaction mixture from $25^{\circ} \mathrm{C}$ to $50^{\circ} \mathrm{C}$. With increase in temperature of the reaction mixture, there was an increase in uranium recovery as well as mean particle size of the uranium cake (Table 5). The precipitation of uranium in presence of $\mathrm{MgO} / \mathrm{NaOH}$ mixture has occurred through formation of small charged, colloid particles called primary nucleus. With rise in temperature of the system, the velocity of the primary nucleus increases as per Boltzman distribution law leading to rise in collision frequency among the primary nucleus. The increase in collision among the primary nucleus increases the probability of bringing the more number of primary nucleuses together to form bigger particle leading to precipitation from the medium. Further, in order to understand the effect of temperature on precipitation of MDU, we need to consider the simplified precipitation mechanism in terms of nucleation and agglomeration (crystal growth). As mentioned in the previous section, the precipitation of MDU proceeds through various chemical reactions (equations 11-13) and to effect nucleation, it is necessary that the solution must be supersaturated. In case of MDU precipitation, a large number of nucleons collide to each other to form agglomerate. So, the formation of MDU agglomerate in such case can be explained in terms of rates of reaction in solution considering two steps (a) problems of encounter rates of nucleus and (b) available activation energy for agglomeration. Now, the encountered particles have two options, either to form agglomerate or to disperse. The overall process can be represented by the following equations:

$$
X_{1}+X_{2} \frac{K_{d}}{K_{-d}} \text { int ermediate } \stackrel{K_{1}}{\longrightarrow} \text { agglomer }
$$

Where $X_{1}$ and $X_{2}$ represent the different kind of nucleons (primary particles) and $K_{1}$ represents the rate of 
agglomeration (crystal growth) ${ }^{[21]}$.Two cases may be arising. In first case, if the rate of dispersion is slow than agglomeration i.e. $\mathrm{K}_{1}>\mathrm{K}_{-\mathrm{d}}$, then the rate of agglomeration will be high. In second case, if the activation energy (Ea) for agglomeration is high, then the rate of agglomeration will be temperature depended. In case of MDU formation, then the rate of agglomeration will be temperature depended. In case of MDU formation, the increase in the agglomeration (particle size) with temperature may be due to involvement of high activation energy during precipitations. Similar results have been observed during precipitation of ADU from uranyl nitrate solution using gaseous ammonia at low gas flow rate ${ }^{[21]}$.

Table 5. Effect of temperature on uranium recovery from carbonate leach solutions. NaOH: $20 \mathrm{~g} / \mathrm{L}$; [HCl]: $11 \mathrm{M}$; Volume of HCl: $75 \mathrm{~mL} / \mathrm{L} ;$ [MgO]: $0.5 \mathrm{~g} / \mathrm{L}$; Stirring speed: $600 \mathrm{rpm} ;[\mathrm{U}]_{\text {feed }}: 0.74 \mathrm{~g} / \mathrm{L}$

\begin{tabular}{cccc}
\hline Temperature, ${ }^{\circ} \mathrm{C}$ & {$[\mathrm{U}]_{\text {filtrate }}, \mu \mathrm{g} / \mathrm{mL}$} & $\%$ U Recovery & Mean diameter, $\mu \mathrm{m}$ \\
\hline 25 & 41 & 94.50 & 9.74 \\
35 & 30 & 94.94 & 11 \\
45 & 22 & 97 & 17 \\
48 & 21 & 97.16 & 22 \\
50 & 15 & 97.97 & 25 \\
\hline
\end{tabular}

\subsection{XRD analysis of uranium cake}

The uranium precipitate prepared from carbonate ore leach solution using $\mathrm{NaOH}$ and $\mathrm{MgO} / \mathrm{NaOH}$ mixture have been studied for phase identification using X-ray diffraction technique. Figure 1 showed the XRD profile of uranium cake prepared using $\mathrm{NaOH}$ and it was found to be sodium diuranate (SDU). Figure 2 showed the XRD profile of uranium cake

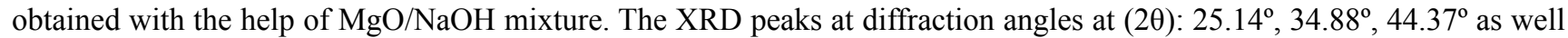
as $55.30^{\circ}$ indicates that the yellow precipitate is magnesium diuranate (MDU). The experimental results showed that the presence of different cations influenced not only the particle size but also the composition of uranium cake. Further, it was observed that the nature as well as charge of cation determined the fate of the negative charge colloid to form precipitate (equation 13). In absence of any $\mathrm{Mg}^{2+}$, the $\mathrm{Na}^{+}$will combine with negative charge colloid to form SDU, where as in presence of $\mathrm{Na}^{+}$and $\mathrm{Mg}^{2+}$, the $\mathrm{Mg}^{2+}$ will combine with negative charge colloid to form MDU. The reason behind formation of MDU in presence of $\mathrm{MgO} / \mathrm{NaOH}$ was because of high positive charge of $\mathrm{Mg}^{2+}$ compared to $\mathrm{Na}^{+}$leading to coagulation of negative charge colloid particles.

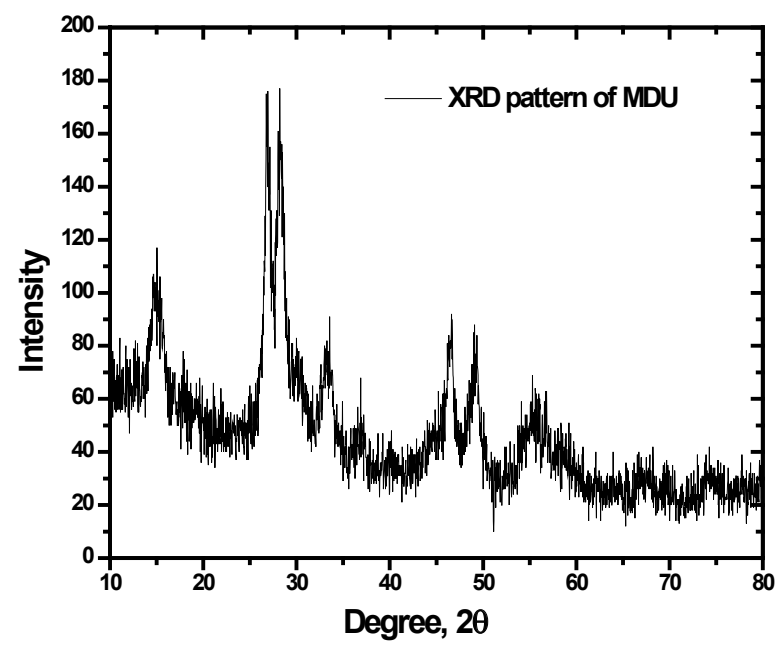

Figure 2. XRD profile of magnesium diuranate (MDU) precipitated from carbonate leach solution using MgO/NaOH

\subsection{Process flow-sheet for uranium recovery}

Based on experimental results an optimized process flow-sheet has been proposed for recovery of uranium from carbonate leach solution containing $<1 \mathrm{~g} / \mathrm{L} \mathrm{U}$ (Figure 3). The carbonate ore was crushed and ground and the ground ore was taken in a leaching tank containing $\mathrm{Na}_{2} \mathrm{CO}_{3} / \mathrm{NaHCO}_{3}$ mixture as leaching reagents. The leaching of uranium was performed under high pressure $\left(9 \mathrm{Kg} / \mathrm{cm}^{2}\right.$ with oxygen partial pressure $\left.5 \mathrm{Kg} / \mathrm{cm}^{2}\right)$ and temperature $\left(135-140^{\circ} \mathrm{C}\right)$. At this temperature and pressure, the leaching efficiency was found to be $\sim 80 \%$. After leaching reaction was over, the solid -liquid separation was performed where leach liquor containing uranium was separated from solid residue. The $\mathrm{pH}$ of the leach 
liquor was $\sim 9$ with a uranium concentration of $0.74 \mathrm{~g} / \mathrm{L}$. In a precipitation reactor containing leach liquor, $\mathrm{HCl}$ was added in controlled manner until the $\mathrm{pH}$ comedown to $\sim$. After acid addition, the solution was heated up to $50{ }^{\circ} \mathrm{C}$ and $\mathrm{MgO} /$ $\mathrm{NaOH}$ mixture was added to it with constant stirring. The solution was left as it is for a period of 1 hour to complete the precipitation. The uranium in presence of $\mathrm{MgO} / \mathrm{NaOH}$ mixture was precipitated as $\mathrm{MDU}$ yellow cake with large particle size (mean particle diameter $\sim 25 \mu \mathrm{m}$ ). Further, the MDU cake was filtered and washed with hot water and dried at 100 ${ }^{\circ} \mathrm{C}$. On the other hand filtrate containing excess $\mathrm{NaOH}$ and $\mathrm{Na}_{2} \mathrm{SO}_{4}$ need to be separated for further reuse. The filtrate after precipitation undergoes freeze crystallization where $\mathrm{Na}_{2} \mathrm{SO}_{4}$ was removed as solid cake. Now the filtrate containing excess $\mathrm{NaOH}$ can be recycled for leaching as $\mathrm{Na}_{2} \mathrm{CO}_{3}$ after passing $\mathrm{CO}_{2}$ through the solution.

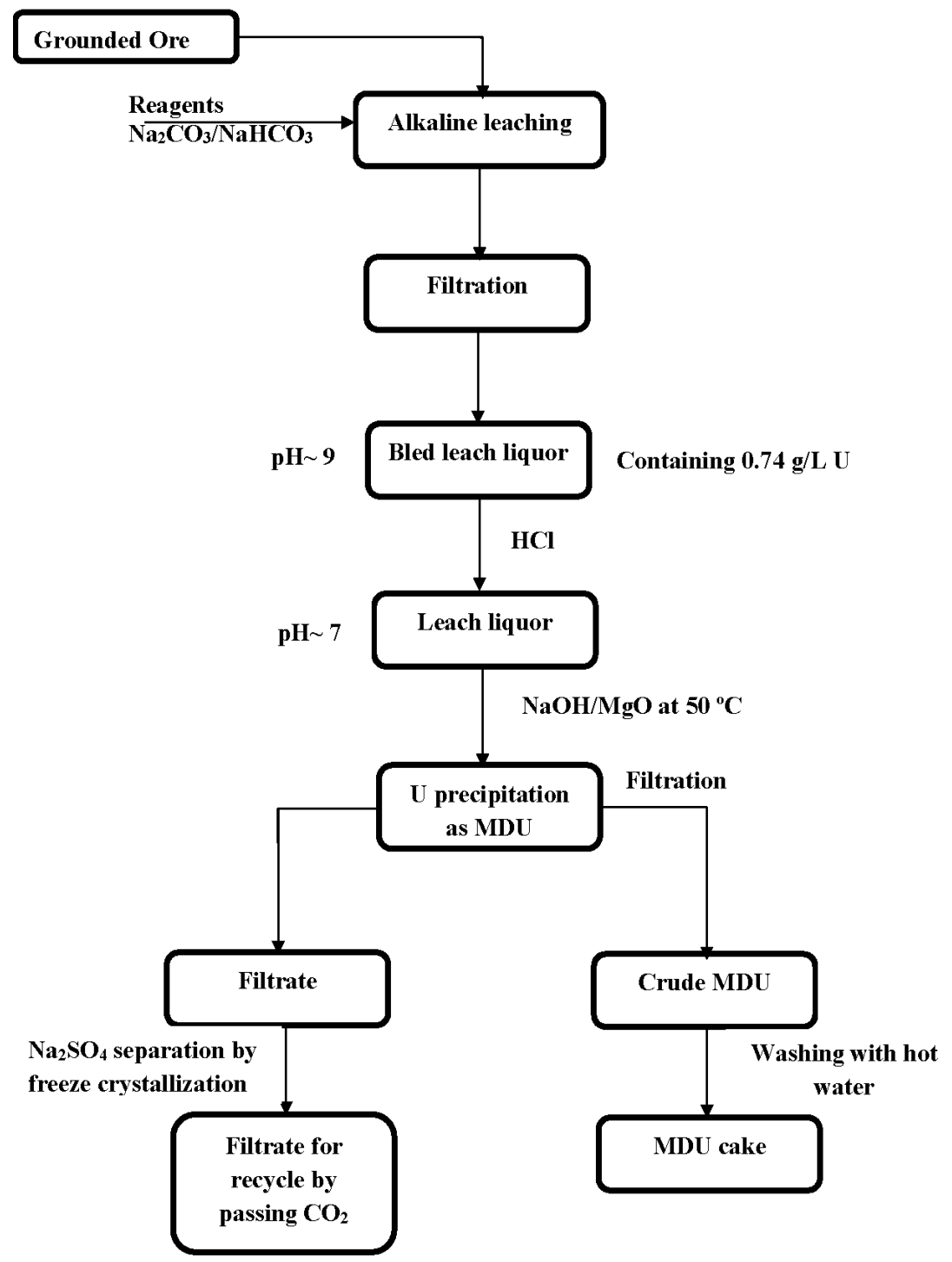

Figure 3. Process flow-sheet for the recovery of uranium from carbonate ore (Tummalapalle, India) leach solution using $\mathrm{MgO} / \mathrm{NaOH}$ mixture

\section{Conclusions}

Recovery of uranium from carbonate leach solution was investigated using a novel precipitating method. The method was based on the removal of carbonate/bicarbonate from the solution using $\mathrm{HCl}$ and precipitation of uranium as MDU using $\mathrm{MgO} / \mathrm{NaOH}$ mixture at $\mathrm{pH} 12.5$. The $\mathrm{XRD}$ study showed that the uranium was precipitated as MDU. The particle size of MDU increased with increased in amount of $\mathrm{MgO}$ as well as with temperature. Based on experimental results a process flow-sheet has been proposed for recovery of uranium from carbonate leach solution. 


\section{Acknowledgements}

The authors thank Director, Materials Group, Bhabha Atomic Research Centre, India for his keen interest in this work. Authors also wish to thank all quality control staff of Uranium Extraction Division for their analytical support during this work.

\section{References}

[1] B. Bhattacharjee. An overview of R\&D in fuel cycle activities of AHWR. 14th Indian Nuclear Society Annual Conference (INSAC); 2003. IT-1 1-27.

[2] A. Kakodkar. Evolving Indian Nuclear Power Programme: Rationale and Perspective. Nuclear India. 2008; 41: 11-12.

[3] T.K. Mukherjee, H. Singh. 14th Indian Nuclear Society Annual Conference (INSAC); 2003. IT-7 1-9.

[4] Integrated Energy Policy, 2006. Report of the Expert Committee. Planning Commission Document. Government of India, p.1-147.

[5] N.P.H. Padmanabhan, A.K. Suri. Challenges in augmenting the uranium supply position in India. International Seminar on Mineral Processing Technology. Mumbai, India; 2007. p.3-18.

[6] A.K. Rai, S. Zakaulla, A. Chaki. Proterozoic stratabound carbonate rock (dolostone) hosted uranium deposits in Vempalle formation in Cuddapah basin, India. International Symposium on Uranium Raw Material for the Nuclear Fuel Cycle, 22-26 June 2009. Austria; 2009.

[7] A.K. Suri. Uranium Processing-A New Alkaline Route. Transaction of Indian Institutes of Metals. 2008; 61(1).

[8] A.K. Suri, S.K. Ghosh. Padmanabhan, N.P.H. Recent pilot-plant Experience On Alkaline Leaching of low Grade Uranium Ore in India. International Symposium on Uranium Raw Material for the Nuclear Fuel Cycle (URAM-2009) 22-26 June. Vienna, Austria; 2009.

[9] A.K. Suri, N.P.H. Padmanabhan, T. Sreenivas, et al. Process development studies for low-grade uranium deposit in alkaline host rocks of Tummalapalle. Presented at IAEA Technical Meeting on low-grade Uranium Deposits at Vienna, 29-31 March; 2010.

[10] A.K. Suri, T. Sreenivas. Developments in processing of conventional uranium ore resources of India. 6th International Mineral Processing Conference (IMPC). New Delhi, India; 2012.

[11] S. Biswas, V.H. Rupawate, K.N. Hareendran, et al. Novel precipitation technique for uranium recovery from carbonate leach solutions. J. Radioanal. Nucl. Chem. 2015; 304(3): 1345-1351.

[12] S. Bachmaf, B. Planer-Friedrich, B.J. Merckel. Effect of sulfate, carbonate, and phosphate on the uranium(VI) sorption behavior onto bentonite. Radiochim. Acts. 2008; 96: 359-366.

[13] A.S. Nagy, L. Zavodska, L. Matel, et al. Geochemistry and determination of possibilities of uranium in natural waters. Acta Tech. Jaur. 2009; 2(1): 19-34.

[14] S.C. Brooks. Waste characteristics of the former S-3 ponds And outline of uranium chemistry relevant to Nabir field research center studies. 2001; ORNL/TM-2001/27.

[15] L.F. Amaral, I.R. Oliveira, R. Salomao, et al. Temperature and common-ion effect on magnesium oxide (MgO) hydration. Ceram. Inter. 2010; 36: 1047-1054.

[16] B. Tomazic, M. Samarzija, M. Branica. Precipitation and hydrolysis of uranium(VI) in aqueous solutions-VI. J. Inorg. Nucl. Chem. 1969; 31: 1771-1782.

[17] B. Tomazic, M. Branica. Precipitation and hydrolysis of uranium(VI) in aqueous solutions-VII. J. Inorg. Nucl. Chem. 1972; 34: 1319-1332.

[18] T. Tsujino, T. Ishihara. Effect of Temperature on the Extraction of Nitric Acid, Uranium and Fission Products with trin-Octyl Amine. J. Nucl. Sci. Technol. 1967; 4: 353-360.

[19] R.M. Rush, J.S. Johnson, K.A. Kraus. Hydrolysis of Uranium(VI): Ultracentrifugation and Acidity Measurements in Chloride Solutions. Inorg. Chem. 1962; 1: 378-386.

[20] B. Tomazic, M. Branica, B. Tezak. Precipitation and hydrolysis of uranium(VI) in aqueous solutions: uranyl nitrate potassium hydroxide - neutral electrolyte. Croat.Chem. Acta. 1962; 34: 41-50.

[21] N.B. Murty, P. Balakrishna, R.B. Yadav, et al. Influnce of temperature of precipitation on agglomeration and other powdwe characteristics of ammonium diuranate. Powder Technology. 2001; 115: 167-183. 